\title{
Žáner balady ako prototext filmovej adaptácie
}

\author{
Ján Sabol (Košice)
}

\begin{abstract}
Abstrakt
Fenoménom filmovej adaptácie sa v poslednej dobe pomerne často zaoberá medialistika, ale aj literárna veda. $\checkmark$ našej práci sa zameriavame na atypický prepis dvoch baladických textov do filmovej podoby, a to: adaptácia najstarších slovenských l'udových balád Javor a Juliana (1972, réžia Štefan Uner) a adaptácia romantických balád K. J. Erbena Kytice (2000, réžia František Brabec). Ked’že základné princípy tvorby baladického textu a charakteristiky tohto žánru sú relatívne známe, zameriavame sa na problematiku genológie a zároveň na problematiku penetrácie a koexistencie lyrických, epických a dramatických prvkov v literárnom texte a následnej filmovej adaptácie. Daná téma má teda širší, nielen literárny, filmový, ale aj antropologický a kultúrny aspekt. V našej práci načrtneme základné predpoklady d’alšieho možného výskumu tejto témy.
\end{abstract}

\section{Kl'účové slová}

film; literatúra; adaptácia; lyrické; epické; dramatické

\section{Abstract \\ Genre Ballad as a Film Adaptation Prototext}

The film adaptation has been relatively frequent in the recent period of medialistics, but literary science has focused mainly on the principles of transcribing the literary text into film form. In our work, we focus on the atypical transcription of two balladic texts into film adaptation of adaptation of the oldest Slovak folk ballads directed by Štefan Uner in Javor and Juliana (1971) and the adaptation of director František Brabec Bouquet (2000). Since the basic principles of the creation of the balladic text and the characteristics of this genre are relatively familiar, we will focus on the issue of genology, and above all on the penetration and coexistence of lyrical, epic and dramatic elements in the literary art and consequently in the film form. The issue has a broader literary, film, but also anthropological and cultural aspect, so we will outline only the basic premise of further possible research on the topic

\section{Key words}

film; literature; adaptation; lyric; epic; dramatic 
Filmovou adaptáciou sa v poslednej dobe pomerne frekventovane zaoberá medialistika, ale aj literárna veda predovšetkým so zameraním na princípy transkripcie literárneho textu do filmovej podoby, ale aj interferencie rôznych postupov na osi literárny text filmové dielo. $\mathrm{V}$ našej práci sa zameriame na atypický prepis dvoch baladických textov do filmovej podoby, a to na adaptáciu najstarších slovenských ludových balád Javor a Juliana (1972, réžia Štefan Uher) a adaptáciu balád K. J. Erbena Kytice (2000, réžia František A. Brabec). Ked’že základné princípy kreovania baladického textu a charakteristika tohto žánru sú pomerne známe, zameriame sa na problematiku genológie, a to predovšetkým na prienik a koexistenciu lyrických, epických a dramatických prvkov v literárnej predlohe a následne vo filmovom tvare. ${ }^{1}$

Literatúra romantizmu má množstvo línií, od monumentálnosti revolučných ideí až po silný individualizmus spojený s hlbokým senzitivizmom a mysticizmom, inšpirovaným svetom stredovekej mystiky a transcendentna, rezonujúcim predovšetkým v žánroch lyriky. A práve tento svet magického romantična ${ }^{2}$ s nádychom tajuplnosti, až hororovosti, ludskej tragédie a fatálnosti konania postáv sa stáva základnou entitou pri stavbe žánru balady. Ak klasicizmus prichádza s princípom hladania harmónie v žánroch ódy a idyly, ktoré majú vo svojej statickej polohe tendenciu k štýlovosti, strohosti, romantizmus prináša introvertný pohlad básnika, ktorý otvára svoj vnútorný svet v množstve osobných, osudových poryvov. Klasicizmus, ale aj v širšom kontexte osvietenstvo, na rozdiel od stredovekého duchovného spiritualizmu preferuje exaktnost̉ a poznanie s mottom sapare aude - odvaha poznat'. Romantizmus odmieta glorifikovanie rozumu, ktorý nedokáže obsiahnut a pomenovat celú prírodu i kozmos. Na rozdiel od klasicistického veršovania popretkávaného ospevovaním prírody v intenciách l'udského rácia, poézia v romantizme "prestáva byt' zábavkou a cvičením, stáva sa poslaním a osudom“."

Madame de Staël člení francúzsku literatúru prelomu 18. a 19. storočia teritoriálne na literatúru juhu a literatúru severu. Literatúru juhu definuje ako literatúru inšpirovanú antickou kultúrou: harmónia, póza, ornamentalizmus, to sú základné znaky tejto literatúry, ktoré sa zosobňujú predovšetkým v žánri idyly a ako d’alej podotýka, tento princíp

1 V našej práci sa budeme pridržiavat klasickej druhovej kategorizácie lyrické - epické - dramatické. Zaujímavé je v spojení s filmovou naráciou rozdelenie druhov podla K. Hamburgerovej, ktorá na rozdiel od aristotelovskej a heglovskej koncepcie pozná len dva druhy: fikcionálny alebo mimetický, do ktorého zahrňuje epickú, dramatickú a filmovú fikciu a na lyrický alebo existencionálny druh.

2 Pojem „romantično“ použili už romantickí nemeckí filozofi. Definovali ho v kontraste s klasicistickou poéziou, pričom romantično (fenomén magiky, tragiky, dynamiky...) nachádzali aj v starých dielach, nielen v textoch romantického literárneho obdobia.

3 „Náhle však (asi roku 1828) jsme se dozvěděli, že existuji romantická a klasická poezie, romantický a klasický román, romantická a klasická óda; ba co dím, drahý pane můj, že i pouhý verš může být romantický nebo klasický, podle toho, jak jej chápeme. Když se k nám donesla táto zvěst, celé noci jsme nespali. Dva roky klidu a jistoty byly ty tam jako pouhý sen. Všechny naše úvahy ovládl zmatek; netvoř́-li již demarkačni linii mezi obéma tábory Aristotelova pravidla, podle čeho se máme orientovat, na co se máme spolehnout? Jak mám poznat, ke které škole patři literárni dilo, jež čteme? Mysleli jsme, že zasvěcenci v Pařiži musi mít nějakou formulku, která ten problém rychle vyřeší, co ale máme dèlat my na venkově? A musím Vám ř́ci, pane, že u nás má slovo romantický lehce pochopitelný význam - je synonymem absurdního a nikdo se o ně zvlášt’ nestará..." Z listu A. De Musseta. In: HRBATA, Zdeněk - PROCHÁZKA, Martin: Romantismus a romantismy. Pojmy, proudy, kontexty. Praha: Karolinum, 2006, s. 290.

MATUŠKA, Alexander: Dielo II. Bratislava: Tatran, 1990, s. 112. 
básnenia je výrazne ovplyvnený stredomorským podnebím a tradíciou tohto regiónu orientovanou na antické ideály. Literatúru severu vníma ako literatúru ovplyvnenú severskou kultúrou, severskými mýtmi a ludovou slovesnostou, túto literatúru, na rozdiel

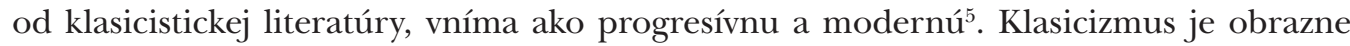
povedané umeleckým smerom šlachty a zámku, romantizmus tento úzus „,ysokej“ kultúry narúša, ponára sa do priestoru l’udovosti a rurálnosti, v ktorom nachádza zásadnú inšpiráciu po formálnej aj motivickej stránke. A práve žáner balady, ako jeden zo základných žánrov romantickej literatúry (a zároveň ludovej slovesnosti), sa stal atypicky primárnym prototextom pre filmové adaptácie Kytice a Javor a Juliana. Tento fakt je zaujímavý predovšetkým z druhového hladiska, ked’že baladický text má predovšetkým lyrický pôdorys, no okrem lyrických prvkov na stavbe baladického textu sa štandardne podiela aj epický a nazdávame sa aj dramatický princíp. Táto z druhového hladiska „komplementárnost“" baladickej výstavby sujetu je blízka aj filmovému jazyku. Spomenuli sme, že lyricko-epický baladický text je atypickým podkladom pre filmovú adaptáciu, je to preto, že stavba filmového sujetu sa konvenčne dáva do korelácie s epickou štruktúrou predovšetkým románového alebo novelistického prozaického textu. Využívanie epických, ale aj lyrických a aj dramatických postupov vo filmovom diele však dokazuje komplementárnosṫ filmovej narácie. Vo vztahu epické - lyrické - dramatické vo filmovom diele prichádza k vzájomnej interferencii prvkov všetkých troch druhových entít, a to v každej rovine filmového diela, vytvárajú sa syntagmatické, koordinatívne, ale aj determinatívne vztahy, pričom miera subjektivizácie určuje zároveň velakrát aj mieru lyrizácie výsledného diela. Ak hovoríme, že základnou vlastnostou epiky je jej sujetovost̉ a zároveň operatívnosṫ v rovine jazyka, teda dialógu, lyrika túto sujetovost' oslabuje využívaním entropie jazyka. Dramatický princíp vytvára akciu, pohyb, „prináša“ frenetickú informáciu. Ak je „epické“ charakterizované modelovaním objektívnej informácie s typickou skôr temporálnostou a kauzalitou, „dramatické“ túto temporálnost' narúša akciou a „lyrické“ snovostou, výraznou mierou subjektivizácie textu. Nič však neexistuje samo osebe, ale vždy v synkretickom tvare s rôznou intenzitou interferencií jednotlivých druhových prvkov, a to v každej rovine textu. Emil Staiger v tejto súvislosti píše: „Každé pravé literárne dielo sa podiela na všetkých druhových ideách rozdielnou mierou aj spôsobom a že odlišnost' tohto podielu je základom neprehladného bohatstva historicky vzniknutých foriem. ${ }^{\text {"6 }}$ Dodajme $\mathrm{k}$ tomu, že diferenciu medzi epickým, dramatickým a lyrickým dielom prvotne určujú nejazykové

5 Pozri TIEGHEM, Phileppe Van: Les grandes doctrines littéraires en France. Paris: Presses Universitaires de France - PUF, 1993. A. Matuška vo svojej kritickosti smerom ku klasicistickej poetike ide ešte d’alej a ku Kollárovmu dielu sa vyjadruje: „Z jeho poézie vanie na nás chlad, hovori málo - nehanbím sa to povedat’ k srdcu a duši, hovori väčsmi k rozumu: vyrastá z ratio a obracia sa $k$ ratio. Hovori to, čo si uzmyslel povedat', nič ponad to; hovori pateticky, vznosne a vznešene i pedantne ako na povinné penzum; obraznost'sa mu rozhára mierne. Nebásni - zbásňuje. Vel'ká väčšina toho, o čom básnil, sa dala povedat aj prózou." In: MATUŠKA, Alexander: Op. cit., s. 92-93.

6 In: PAŠTEKA, Július: Estetické paralely umenia. Bratislava: VEDA, 1976, s. 167. Ďalej E. Steiger dodáva: „Literárne dielo, ktoré by bolo ,celkom epické" alebo, celkom dramatické" (v knihe Lyrické prvky vo filmovej štruktúre sme podotkli a doplnili celkom lyrické), je nemyslitelné, pretože každé literárne dielo má podiel na všetkých druhoch a len isté ,viac' alebo ,menej' rozhodne o tom, či toto dielo nazveme ,epickým', ,dramatickým' alebo ,lyrickým'. " Tamže, s. 167. 
rozdiely v ich štruktúrach. ${ }^{7}$ Podobné prepájanie znakov všetkých troch druhových entít nachádzame aj vo filmovej štruktúre. Emil Staiger sa vyhýba striktnému vymedzeniu literárnych druhov na lyriku, epiku a dramatiku, využíva skôr adjektívne formy „lyrické“, „epické“, „dramatické“. Ako poznamenáva, dá sa určit, čo je „to“ „lyrické“, „epické“, „dramatické“. Literárne dielo tak podla Staigera môže byt viac lyrické, epické alebo dramatické. Logické teda je, že najviac epického je v epike, lyrického v lyrike, dramatického v dramatike. A ako d’alej dodáva: „Každý človek má vraj v sebe akúsi ideu „lyrického“, skrsla $v$ ňom kedysi pri určitej príležitosti a nemusi mat’ nič spoločného s umeleckým dielom. Mohlo sa tak stat’ pri vnimani istej krajiny “ ${ }^{8}$ Prirodzene filmový jazyk, podobne ako literárny text, má svoje špecifické vlastnosti, neexistujú však štandardy transformácie literárnej predlohy do filmového tvaru. Dá sa povedat, že čo adaptácia, to originálny spôsob „prepisu“ literárneho jazyka do filmovej reči. ${ }^{9}$

Pre baladu je typická synkretickost́. Tento synkretický charakter je kreovaný lyrickými, epickými a podotýkame aj dramatickými prvkami v texte. Nemenej dôležitý je v súvislosti s filmovými adaptáciami aj fakt, že na tempickej a rytmickej rovine zohrával dôležitú úlohu pôvodný spevný charakter baladického textu. V kontexte komparácie filmových adaptácií Javor a Juliana a Kytice spomenieme, že aj ked' je baladický žáner prototextom pre obidve adaptácie, v prvom prípade ide o prepis l’udových balád z najstaršieho tematického okruhu siahajúceho do ranostredovekého obdobia, v druhom prípade ide o adaptáciu umelej balady z romantického literárneho obdobia, aj ked' výrazne inšpirovanou l’udovými textami. Tento fakt je dôležitý v súvislosti s výsledným filmovým tvarom, jeho atmosférou a prvkami, ktoré jednotlivé filmové diela využívajú k prepisu pôvodného literárneho materiálu. Prirodzene sa na výslednom tvare obidvoch filmov podpísala aj technologická vyspelosṫ filmového spracovania. Obdobie od sedemdesiatych rokov po začiatok tohto storočia poznamenal výrazný technologický posun, ktorý ovplyvnil digitalizáciou aj filmový jazyk. Základný rozdiel medzi obidvoma adaptáciami je aj v sujetovej štruktúre. V súvislosti s filmom Javor a Juliana spomenieme predovšetkým parataktickú kompozíciu filmovej štruktúry, pre ktorú je symptomatické lineárne kreovanie príbehu. Tento spôsob je najstarším princípom budovania sujetu existujúcim už v indoeurópskom základe čarodejných rozprávok, neskôr nachádzajúci sa aj v žánri eposu. V tomto prípade je dôležitou kompozičnou zložkou postava (postavy putujúce rôznymi priestormi), ktoré sa stávajú v kompozícii, v architektonike textu sponou. Vo filmovom diele Kytice ide skôr o samostatne existujúce časti realizované „klipovitou“ formou uzavretých celkov, priradených k lineárnej štruktúre diela. Zásadným rozdielom medzi filmovými adaptáciami je ich prototextový materiál, ten určuje výrazným spôsobom aj výsledný charakter filmových diel. Spomenuté filmové autorské prepisy rešpektujú pôvodný baladický materiál.

7 Tamže, s. 167.

8 Pozri STEIGER, Emil: Základni pojmy poetiky. Praha: Československý spisovatel, 1969 a KRAUSOVÁ, Nora: Epika a román. Bratislava: Slovenský spisovatel', 1964, s. 37-38.

9 A. Helmanová rozdel’uje adaptáciu na transpozíciu (ktorá zachováva vernost voči originálu), komentár (metóda, ktorá zachováva iba základnú sujetovú kostru) a analógiu (pri adaptácii vzniká výrazne iný text, ktorý preberá len určité kompozičné motívy). I. Stadtrucker hovorí o transkripcii, analógii a improvizácii, ale ich význam je totožný s klasifikáciou A. Helmanovej. 
Z tohto aspektu je zaujímavé, akým spôsobom sa v jednotlivých rovinách filmu zhmotňujú obidva princípy: l’udový a umelý, romantický. Romantická literatúra výrazným spôsobom využíva znaky ludovej balady, a to vo viacerých segmentoch štruktúry textu, no medzi kompozíciou l’udovej a umelej balady je aj zásadný rozdiel. Ludová balada je postavená výsostne na orálnom princípe reprodukcie textu, to znamená, že jej kompozícia má jednoduchšiu štruktúru, postavenú na ustálených štylistických a jazykových prostriedkoch, vhodných na memorovanie prednášaného textu. Táto strohost', jednoznačnosṫ vo výstavbe textov ludovej slovesnosti sa prenáša do všetkých rovín textu, aj do výstavby sujetu a charakteru postáv. Pre l’udový epický (lyricko-epický) text je typická lineárnost výstavby sujetu a absencia psychologizácie postáv, ktoré majú často nadnesené charakterové vlastnosti v schematickej štruktúre dobré - zlé, morálne - nemorálne. ${ }^{10}$ Štruktúra romantickej balady, oproti l’udovej, je bohatšia, predovšetkým je to zrejmé pri využívaní básnických figúr a existencii originálneho autorského jazyka. Dôkazom toho sú nielen samotné balady K. J. Erbena, ale aj ich filmová adaptácia, ktorá podobne ako adaptované prototexty má predovšetkým vo využívaní znaku, symbolu a v použití básnických figúr aj vo vizuálnom tvare filmového jazyka ovela väčšie zastúpenie, a to v rôznych koreláciách na rozdiel od l'udového textu balady a jeho adaptácie vo filme Javor a Juliana. Pre percipienta je to markantné hned' vo vizuálnej zložke filmu využívaním bohatej farebnosti nielen samotného záberu, ktorý vytvára často pocit expresívnosti v kontraste s impresionistickou náladou bezproblémovosti (napr. v časti Vodnik), ale aj využívaním farieb ako dôležitého symbolu, kódu pri percepcii filmového diela. Umelá balada často využíva princíp kontrastu, ktorý môže mat aj charakter rámcovania samotného textu. Do opozície sa dostáva expozičná čast’ s jadrom textu, pričom finále navracia percipientovi atmosféru expozičnej časti. Fenomén kontrastu v baladickom texte výrazne sa prezentujúci aj vo filmovom texte, možno pozorovat’ na niektorých často sa vyskytujúcich opozičných variantoch. V rovine symboliky farieb: (adaptácia balady Vodnik): zatial' čo pôvodný baladický verš využíva fenomén bielej farby ako farby čistoty a nevinnosti, panenstva, ale zároveň s ambivalentým charakterom symboliky smrti:
„Perly jsem tobě vybirala, / bile jsem tebe oblikala, / v sukničku jako z vodnich pěn: / nechod', dceruško, $k$ vodě ven.
Bilé šatičky smutek taji, / v perlách se slzy ukrývaji, / a pátek neštastný je den, / nechod', dceruško, $k$ vodě ven." -

film vizuálne vytvára bohatšiu škálu farebnosti a kontrastnosti. Bielu často dáva do kontrastu s červenou, čiernou farebnou symbolikou. Viaceré farebné symboly však majú ambivalentný charakter, $\mathrm{v}$ tomto prípade červená predznamenáva erotizmus, stratu

10 „Opisované ludské vlastnosti sú postavené do zvláštneho svetla tým, že sú zveličené, prepiate a nadnesené. Hlúpost', zlo alebo zradnost' sú ako pod zväčšovacím sklom ešte hlúpejšie, horšie a zradnejšie, kým odvaha, dobré srdce a šikovnost' sú zase zidealizované. Preto má spôsob tvorenia postáv vo folklóre tomu, čo sa zvyčajne nazýva čierno-bielou technikou. Každá postava je úplne dobrá a vel'komyselná, alebo úplne zlá a zavrhnutiahodná - stredná cesta medzi nimi neexistuje." In: LEŠČÁK, Milan - SIROVÁTKA, Oldřich: Folklór a folkloristika. O l’udovej slovesnosti. Bratislava: Smena, 1982, s. 212. 
panenstva, vášeň, ale zároveň aj pokušenie, krv, a teda aj smrt’. Kontrastný princíp je jedným zo základných princípov pri budovaní baladického textu v romantickej literatúre, obrazne umocnený je aj v adaptovanom filmovom diele, spomenieme niektoré d’alšie: deň (svetlo) - noc (tma, spln): klasický, až archetypálny kontrastný princíp nachádzajúci sa v l'udovej slovesnosti a ranostredovekých textoch (rozprávky, mýty, báje, eposy atd’) vychádzajúci z prirodzeného ludského strachu z tmy, niečoho nepoznaného. „Hocako vel'ká racionalizácia, reforma myslenia či freudouská analýza preto nedokážu celkom potlačit' rozochvenie z príbehov rozprávaných pri praskajúcom kozube či strachu z opusteného lesa. Ide tu o psychologický archetyp alebo tradiciu..."11 a d’alej H. P. Lovecraft v tomto kontexte dodáva, „deti sa vždy budú bát tmy a l'udia citlivi na dedičný impulz sa vždy zachvejú pri pomyslení na skryté bezhraničné svety podivného života, ktorý možno pulzuje kdesi d’aleko, v priepastiach za hviezdami, alebo desivo pôsobi na našu planétu, s obludnostou, ktorej nečisté rozmery dokážu prehliadnut’ iba mŕtvi či šialenci“. ${ }^{12}$ Medzi d’alšími kontrastmi môžeme spomenút výskyt horálneho času v opozícii s dňom, svetlom, brieždením. Horálny (magický) čas sa stáva základným stavebným princípom romantickej balady, ale aj filmovej adaptácie atd'. Filmový jazyk teda často využíva symboly, znaky, ktoré vytvárajú vo vzájomnej paradigme rôzne konotácie. Znakové štruktúry ${ }^{13}$ tak vo filmovom zábere nemusia byt nositel'mi sémantickej informácie len v izolovanej pozícii, teda stojace samy osebe a „pre seba“, ale často takúto informáciu ponúkajú až v kontexte filmovej skladby, syntaxe. „Socha hodená do trávy môže vytvorit’ nový umelecký efekt vzhl'adom na vznik vzájomného vzt’ahu medzi trávou a mramorom. Táto zuláštnost' sa spája, ako sme videli, so štruktúrnym princípom, ktorý určuje mnohoznačnost' umeleckých prvkov; nové štruktúry svojím vstupom do textu alebo do mimotextového pozadia umeleckého diela nerušia staré významy, ale vstupujú s nimi do nových sémantických vzt’ahov. "14 Pripomeňme, že pôvodný l'udový baladický materiál mal spievanú podobu, čoho dokumentom je aj v incipite filmu Javor a Juliana zhudobnenie pôvodného textu o dievčati v javor zakliatom. V expozičnej časti filmového diela je pretransformovaný prvý baladický spomenutý text o dievčati v javor zakliatom, z neho prechádzajú do filmovej štruktúry hned' dva základné motívy; motív zakliatia dcéry vlastnou matkou a motív hudcov. Druhý spomenutý motív sa vo filmovom diele dostáva do polohy základného kompozičného princípu. Práve vd’aka motívu hudcov, ktorí vo filmovom diele putujú rôznymi priestormi, čím spájajú jednotlivé baladické texty do konzistentného celku, dostáva sujetový pôdorys filmu parataktický (lineárny) charakter. Podobný princíp využíva

11 LOVECRAFT, H. Phillips: Nadprirodzená hrôza v literatúre. Bratislava - Pezinok: Agentúra Fischer-Formát, 1997, s. 6.

12 Tamže, s. 8.

13 „Barthes rozlišuje lingvistické (symbol) a psychologické (analogón) chápanie znaku. Nehovorí o znaku, pretože koncept konvenčného znaku považuje vzhl'adom na obrazovú podstatu filmu za nedostatočný. Nahrádza ho pojmom psychologického analogónu (v zmysle: obraz analogický realite) chápaného ako znak velmi špecifický. Súvisí to s Mitryho známym výrokom o tom, že film nemá jazyk: ,Film nie je lingvistický systém znakov a symbolov, ako estetickú formu výrazu používa obrazy, ktoré samy osebe sú prostriedkom expresie. V súlade s typom rozprávania sa organizujú do systému znakov a symbolov, teda jazyk tvoria. Ale je to jazyk druhého stupña, umelecký jazyk, lebo existuje výlučne v systéme vnútornej organizácie, ktorou je dielo. Neexistuje pred dielom ani mimo neho." In: CIEL, Martin: Pohyblivé obrázky. Levice: Koloman Kertézs Bagala, 2006, s. 120. 
aj filmová adaptácia Kytice, princíp paholka, postavy hrajúcej na píštalke (v balade Zlatý kolovrat sa dostáva postava do klasického operatívneho dialógu so starým „pútnikom“). Hudobný motív sa však vo filme Kytice nestáva bazálnym kompozičným motívom, má skôr rámcujúci charakter „klipovitých“ zobrazení jednotlivých balád s odkazom na spievaný charakter baladického textu.

Interferencia lyrických, epických a dramatických princípov je markantná vo viacerých rovinách spomenutých adaptácií. Spomeňme obrazovú štylizovanost̉ vo filme Kytice, ktorá často vytvára lyricko-dramatickú kontrastnost’, oproti „epickej“ strohosti v realizovanej adaptácii Javor a Juliana, v rovine postáv a v dialogickej rovine (lyrické, iracionálne verzus epické, realistické). Zatial' čo vo filmovom diele Kytice nastáva akt komunikácie medzi postavami len prostredníctvom poézie, teda veršovým spôsobom, v druhom sa sujet filmového diela realizuje putovaním hlavných postáv, troch hudcov, medzi ktorými prebieha klasická operatívna komunikácia, ktorá sa v pôvodnom texte nenachádza. Autorský, dramaturgicko-scenáristický vstup do pôvodných baladických textov tým dodáva výslednému tvaru výraznejší epický charakter. ${ }^{15}$

V závere môžeme dodat, že opozícia lyrické - epické sa spája paralelne s terminológiou prevzatou z psychológie, a to s pomenovaniami tenzia a detenzia, ktoré súvisia s faktom využívania homeostázy u človeka. Práve túto metodológiu aplikuje vo svojej teórii aj František Miko. Miko dodáva, že tenzia a redukcia tenzie sa v literárnom texte realizujú $\mathrm{v}$ dvoch jeho rovinách; $\mathrm{v}$ tematickej rovine ako konflikt a spôsob jeho riešenia a v tvarovej, formálnej rovine na úrovni zvukovej a rytmickej štruktúry textu a d’alej dodáva: „Konflikt a jeho riešenie v epike, $t$. $j$. tematická tenzia a detenzia sú v podstate analógiou životnej, široko chápanej stresovej situácie a jej objektívneho riešenia. Pritom treba poznamenat', že tzv. objektívne riešenie je len jedno z možných, je to vlastne adekvátne riešenie. "16 Fenomén tenzie však nevzniká u človeka len v lyrickej situácii, ale je základným princípom aj dramatického konania postáv. Lyrika a dramatika tak akoby vychádzali z podobného zdroja emocionálnej výpovede v kontraste s epickou „bezproblémovostou“. Rozdiel medzi lyrickým a dramatickým je však v intenzite informácie, ktorú poskytuje. Dramatika pracuje s vypätou emocionálnou situáciou, lyrika s emocionálnym uvol’nením. Tieto princípy však v rôznych textoch vytvárajú mnohovrstvové štruktúry, tak ako sme na to poukázali vyššie, umelecké dielo existuje len v korelácii a vzájomnej influencii týchto troch druhových entít. Genologické úvahy vychádzajú z princípov literárnej teórie, ich aplikácia však ide nad rámec literárnej vedy a je použitel'ná pri interpretácii nielen literárnych diel. Táto problematika má teda širší literárnoteoretický, filmový, ale aj antropologický a kulturologický rozmer, preto sme v našom texte načrtli len základné premisy d’alšieho možného výskumu danej témy.

15 „V teórii literatúry sa všeobecne prijima turdenie, že obyčajná l’udská reč a prozaická reč sú totožné, a že preto je próza vo vztahu $k$ poézii prvotným, predchádzajúcim javom. [...]. Predpokladom na usudzovanie o jazyku je axióma, že prirodzenou formou organizovanej l’udskej reči je próza.“ In: LOTMAN, J. M.: Štruktúra umeleckého textu. Op. cit., s. 15. V tomto kontexte J. Lotman dodáva: „Takto sa protiklad „próza - poézia“ stáva špecifickým vyjadrenim protikladu „neumenie - umenie“. Nie náhodou paralelne s premiestňovaním diela v sémantickom poli „poézia - próza“ prebieha nepretržité začleñovanie „neumenia“ do sféry umeleckých textov a „vytláčanie“ diel umeni a celých žánrov do oblasti „neumeleckých“. Tamže, s. 119.

16 MIKO, František: Od epiky k lyrike. Štylistické prierezy literatúrou. Bratislava: Tatran, 1973, s. 92. 


\section{Literatúra}

CIEL, Martin: Pohyblivé obrázky. Levice: Koloman Kertézs Bagala, 2006.

DELEUZE, Gilles: Film 1. obraz - pohyb. Praha: Národní filmový archiv, 2000.

DELEUZE, Gilles: Film 2. obraz - čas. Praha: Národní filmový archiv, 2006.

HELMANOVÁ, Alicja: Tvořivá zrada. Filmové adaptace literárnich děl. In: Tvořivé zrady. Současné polské myšlení o filmu a audiovizuální kultuře. Praha: Národní filmový archiv, 2005, s. 133-144. HRBATA, Zdeněk - PROCHÁZKA, Martin: Romantismus a romantismy. Pojmy, proudy, kontexty. Praha: Karolinum, 2006.

KRAUSOVÁ, Nora: Epika a román. Bratislava: Slovenský spisovatel, 1964.

LEŠČÁK, Milan - SIROVÁTKA, Oldřich: Folklór a folkloristika. O ludovej slovesnosti. Bratislava: Smena, 1982.

LOTMAN, J. M.: Štruktúra umeleckého textu. Bratislava: Tatran, 1990.

LOTMAN, J. M.: Semiotika filmu a problémy filmovej estetiky. Bratislava: Slovenský filmový ústav, 2008.

LOVECRAFT, H. P.: Nadprirodzená hrôza v literatúre. Bratislava - Pezinok: Agentúra Fischer-Formát, 1997.

MATUŠKA, Alexander: Dielo II. Bratislava: Tatran, 1990.

MIHÁLIK, Peter: Kapitoly z filmovej teórie. Bratislava: Tatran, 1983.

MIKO, František: Od epiky k lyrike. Štylistické prierezy literatúrou. Bratislava: Tatran, 1973.

MIKO, František: Umenie lyriky. Bratislava: Slovenský spisovatel', 1988.

PAŠTEKA, Július: Estetické paralely umenia. Bratislava: VEDA, 1976.

STEIGER, Emil: Základni pojmy poetiky. Praha: Československý spisovatel, 1969.

STADTRUCKER, Ivan: Dramaturgia hraného filmu. Bratislava: Tatra, 1990.

TIEGHEM, Philippe Van: Les Grandes doctrines littéraires en France. Paris: Presses Universitaires de France - PUF, 1993.

doc. Mgr. Ján Sabol, PhD., ArtD.

Katedra slovakistiky, slovanských filológií a komunikácie

Filozofická fakulta, Univerzita Pavla Jozefa Šafárika

Šrobárova 2, 04059 Košice, Slovensko

jansabol@yahoo.com 